\title{
Culture and Innovation in Essay Writing Project: EFL Students' Perceptions
}

\author{
Bambang Yudi Cahyono \\ Universitas Negeri Malang, East Java, Indonesia
}

\begin{abstract}
Two important concepts in education nowadays are "culture" and "innovation." Culture is important as it goes along with the way people think, feel, and do and their phases of life, while innovation is important as it suggests development. In the context of education in the globalization, culture reflects identity, while innovation reflects creative products beyond conventional practices. This small-scale study examined EFL students' perceptions on the essay writing project incorporating both culture and innovation. It involved 25 students attending an essay writing course in the English Department of a state university in Indonesia, Following the completion of the teaching and learning actvites: the students' perceptions were elicited on the basis of three criteria: development of idea for writing, meaningfulness of the writing project, and writing competence of the students. The results showed that the EFL students perceived combination of local culture and innovation in the form of video making helped them developing essays. They also thought that the essay writing project was meaningful and they felt that their writing competence improved after following the writing project.
\end{abstract}

Index Terms - culture, innovation, essay writing, essay writing project

\section{INTRODUCTION}

Embracing culture and innovation in education is like bringing together things inherited from the past and the things wanted to be in the future. Combination of the two concepts requires the maintenance of the cultural contents and at the same time the presentation of the cultural contents in a new way. According to Hinkel (1999), "there are nearly as many definitions of culture as there are fields of inquiry into human societies, groups, systems, behaviors, and activities" (p. 1). More specifically, the term culture can be defined as "the customs and beliefs, art, way of life and social organization of a particular country or group" (Wehmeier, 2005, p. 373). Meanwhile, the term innovation refers to "the introduction of new things, ideas, or ways of doing something" (Wehmeier, 2005, p. 801). This article aims to integrate culture and innovation by focusing on cultural contents and the way to present the cultural contents.

A review of the literature suggests that culture and language are interrelated. The relationship between language and culture is shown vividly in Brown's (2001) words, suggesting that "one cannot separate the two without losing the significance of either language or culture" (p. 165, cited in Zu \& Kong, 2009). Theoretically, there are opposing views with regard to the role of culture in second language learning. On the one hand, it is emphasized that local culture should be given a priority. Thus, when teaching English, English language teachers should use the target language as a means to deliver messages about the speakers' culture, preserving their cultural identity. This is supported by the understanding that English-as-a-foreign-language (EFL) learners have been grown up in their own culture. Therefore, the way they think, feel, and act is the product of their own culture and it affects how they learn the target language. For example, Imran's (2005, p.8) study showed that EFL learners' cultural background affected their reading performance in a negative way. She found out that EFL learners would not interact much in the instructional process and would not contribute to class discussion regardless of their knowledge on the topic due to their cultural resistance (i.e., "unwillingness to be put at risk of being mocked by their classmates").

On the other hand, the proponents of the importance of target culture suggest that when teaching English, English language teachers are expected to use target culture as a means to learn the language, or vice versa, using the English language to learn the target culture. According to Luciana (2005) target language culture should be emphasized over local language culture because the teaching of English in general aims at preparing learners to take part in the era of globalization. She provided four reasons for the inclusion of target language culture, namely "the development of cultural platform; students' broadmindedness; intelligibiliity consideration; and the nature of the English language heavily laden with its culture" (p. 78). In this sense, based on Luciana's proposals, target culture may be used to enrich the learners' awareness of their own culture, to make them understand that there is another culture beyond their daily life, to develop competences in using English language which is globally comprehensible, and to avoid problem of misunderstanding. In Luciana's words, English and (culture content) that should be taught to EFL learners is one that can help them "see and explore the world", not "English that confines them in their own world" (p. 78).

Apart from the option that either the local culture or the target culture should be taught, there is another alternative that combines the local culture and target culture. The combination of local culture and target culture conforms to the idea proposed by Kramsch (1998). Kramsch suggested an alternative of the inclusion of both types of culture contents 
in order to establish awareness of 'interculturality.' Interculturality refers to the integration of knowledge of target language culture and local language culture in the context of language learning. Thus, learners can use their knowledge of local culture as a basis for understanding target culture. In Kramsch's (1998) words, it is used to refer to "the ability to acquire another person's language and understand someone's culture while at the same time retaining one's own" (p. 81). The opinions of the teachers also conform to the results of a research study conducted by Asmiyah (2009). In her study of the inclusion of Islamic topic for the teaching of English, she found out that Islamic topics cannot be included exclusively without integration with target language culture. Thus, to promote interculturality, she recommended that EFL learners of from Islamic colleges be taught using more varied contents, including Islamic and Western culture contents.

In addition to the types of culture contents to be included in ELT, an important issue deals with the topics that need to be included when using culture contents. With regard to topics for culture contents, it is worthwhile to consider the topics proposed by Cortazzi and Jin (1999, p. 203) as can be seen in Table 1.

TABLE I

TOPICS FOR CULTURE CONTENTS

\begin{tabular}{ll}
\hline No & Topics \\
\hline 1 & Social identity and social groups (social class, regional identity, ethnic minorities) \\
2 & Social interaction (differing levels of formality) \\
3 & Belief and behavior (moral, religious beliefs, daily routines) \\
4 & Social and political institutions (state institutions, health care, law and order, social \\
& security, local government) \\
5 & Socialization and the life cycle (families, schools, employment, rites of passages) \\
6 & National history (historical and contemporary events seen as markers of national identity) \\
7 & National geography (geographic factors seen as being significant by members) \\
8 & Stereotypes and national identity (what is "typical," symbols of national stereotypes) \\
\hline
\end{tabular}

It has been shown in the literature that cultural contents can be presented in various ways in the teaching of language. Rokhyati (2005) stated that when teaching English, cultural contents can be introduced through the use of authentic texts. However, she added that the authentic texts to be used to teach English should be "suitable for the students' level of competence and understanding" (p. 55). This is also the case with the textbooks used in the teaching of English. In their analysis of a textbook used in the teaching of English in China, Learning English, Zu and Kong (2009, p. 116) found out that materials oriented to target culture are introduced directly (e.g., through "words accompanied by pictures" and "situational dialogs") and indirectly (e.g., through "values, attitudes, and world outlooks that are vital to the understanding of language"). Thus, culture contents have been presented in a conventional way by using printed materials in the forms of texts and textbooks.

In this study, the students were provided with practices in using local culture contents in a writing project. Local culture contents are used because they are available in the students' environment, accessible by the medium owned by the students, and, thus, more practical than the target culture contents. The innovative element in this project concerns with the process of video-making of the settings related to the topics and the presentation of the students' essays. The final products of the students' essays are in the form of printed texts based on video recordings of topics on culture contents. Some previous studies (e.g., Cahyono \& Rahayu, 2015; Nurcahyasari, 2015) addressed the use of videos in English language teaching. More particularly, Nurcahyasari (2015) suggested some procedures in applying materials from the videos for teaching various English language skills. In contrast, the present study deals with the videos made by the students to help themselves develop ideas in writing. Meanwhile, Cahyono and Rahayu (2015) reported the use of videos in supporting the students to work with process-analysis essay. The videos used in their study were made by the students who wrote the essay. Unlike Cahyono and Rahayu's study, this study focuses on the use of video to help students develop their ability in writing an exemplification essay.

Reflecting upon the background, this study examined the students' perceptions on the culturally and technologically oriented essay writing projects. It has three research questions as follows:

1. How do the students perceive the video-making project as a means of developing ideas for their essays?

2. How do the students perceive the meaningfulness of the essay writing project?

3. How do the students perceive their competence after working on the essay writing project?

\section{METHOD}

This study used a survey method to find out students' perception on the culturally and technologically oriented essay writing project. It involved 25 students who were attending Essay Writing course at Universitas Negeri Malang at the first semester of 2017/2018 academic year. At the University, writing skill is taught in a series of three courses: Paragraph Writing, Essay Writing, and Argumentative Writing. In Essay Writing course, in particular, students learn to write essays of five development patterns: exemplification, comparison and contrast, classification, process-analysis, and cause and effect analysis (Catalogue of the Department of English, 2017). This study specifically dealt with the exemplification essay, a five-paragraph essay which is developed by using examples. The first paragraph is the 
introduction which contains the thesis statement. The second, third, and fourth paragraphs are developmental paragraphs, or the body part of the essay. The last paragraph is the concluding paragraph.

The exemplification essay was taught in six sessions (see Table 2 for the teaching schedule). In the first session, students were introduced to the theoretical basis of the exemplification essay.

TABLE II

THE TEACHING SCHEDULE

\begin{tabular}{ll}
\hline Session & Activities \\
\hline 1 & $\begin{array}{l}\text { introduction to example essay, explanation on the project, and group discussion } \\
\text { of the topic }\end{array}$ \\
& $\begin{array}{l}\text { Practice on composition skills, analysis of model essay, and group discussion of } \\
\text { the documentation plan }\end{array}$ \\
3 & $\begin{array}{l}\text { Presentation on the documented examples (by some groups) and individual essay } \\
\text { writing (the introductory paragraph and developmental paragraph 1) }\end{array}$ \\
4 & $\begin{array}{l}\text { Presentation on the documented examples (by the rest of the groups); teacher } \\
\text { feedback on thesis statement and topic sentence of the first development } \\
\text { paragraph); and individual essay writing (developmental paragraphs } 2 \text { \& } 3 \text {, and } \\
\text { the concluding paragraph) } \\
\text { Teacher feedback on topic sentences of the second and third development } \\
\text { paragraphs and the concluding paragraph } \\
5\end{array}$ \\
& $\begin{array}{l}\text { Submission of the printed essay of the students and distribution of questionnaire } \\
\text { on students' perception on the project on culture and innovation on essay writing }\end{array}$ \\
\hline
\end{tabular}

To teach how to write an exemplification essay, the textbook on "The Exemplification Essay" from Smalley, Ruetten, and Kozyrev (2001, pp. 137-147) were used as the material. From the textboo, the students read a model text entitled "Americans are Friendly to Strangers." They were also informed that they had to work on a culturally and technologically oriented writing project with the following instructions:

1. Work in groups of 3, 4, or 5 students to discuss about a topic for an essay.

2. Write a thesis statement showing a method of development by using examples.

3. Document the examples in the form of using videos, pictures, or drawings.

4. Do the documentation process in groups and write the essay individually.

In the second session, they were given practices on composition skills from the same source. They learned how to write "Transitions between Paragraphs" (Smalley et al., 2001, pp. 143-144). They were also asked to read another model of exemplification essay entitled "Words that Camouflage." In the end of this session, they were asked to work with members of their groups to discuss the plan for the documentation of the settings related to the topics of their essays. There were six groups of students.

In the third and fourth sessions, the students presented the documented settings in the forms of movies and images delivered through power points. The six groups of students presented six topics of exemplification essays, namely:

1. Malang Iconic Parks (4 students)

2. Car Free Day at Idjen Boulevard, Malang (4 students)

3. The Most Famous Universities in Malang (4 students)

4. The Iconic Food of Malang (4 students)

5. Facilities at English Self-Access Centre, Universitas Negeri Malang (5 students)

6. The Most Frequently Visited Canteens at Universitas Negeri Malang (4 students)

Based on the types of topics proposed by Cortazzi and Jin (1999), the topics of the students' essays can be included into "belief and behavior" (Topic 2), "social and political institutions" (i.e., Topics 3, 5, and 6), and "stereotypes and national identity" (i.e., Topics $1 \& 4$ ).

Following the presentation of the documented settings in the third session, the students were asked to write the introductory paragraph and the first developmental paragraph individually. After the presentation of the documented settings in the fourth session, the students showed the drafts of their individual essays assigned in the previous session. They got feedback from the lecturer regarding their thesis statement and topic sentence, Furthermore, the students were asked to continue working on their essays, covering the second and third developmental paragraphs and the concluding paragraph.

In the fifth session, the students got feedback on their second and third developmental paragraphs focusing on the relevance of the topic sentences and the use of transition markers between paragraphs. They were also informed that they had to submit their printed essays in the next session. In the sixth session, they students submitted their essays to the lecturer. One of the students' essays on "The Most Famous Universities in Malang" was used as an example as attached in Appendix A.

They were then given a questionnaire to elicit their perceptions on the Culturally and Technologically Oriented Essay Writing Project (See the Questionnaire in Appendix B). The questionnaire, which consisted of three parts, aimed to know how the students see the process in developing ideas into essay in relation to the essay writing project. The first part of the questionnaire had four questions. The questions dealt with whether or not the process of video-making project helped them in (1) determining the topic for the essay, (2) developing the topic in the thesis statement, (3) expanding the thesis statement into the developmental paragraphs, and (4) writing the concluding paragraph. 
The second part of the questionnaire asked the students' perceptions on the meaningfulness of the essay writing activities (5 items), while the third part asked the students regarding their competence in writing (5 items). The two parts of the questionnaire were based on Likert-scale with five options varying from "strongly agree" to "strongly disagree." The questionnaire was based on one made by Yujing (2015) and modified to suit the purpose of this study. All of the 25 students responded to the questionnaire.

\section{RESULTS}

The three research questions are used as a basis to present the results of this study. The first research question concerns how the students perceived the video-making project as a means of developing ideas for their essays. There were four questions in the first part. The students had to answer the questions by choosing the options "Yes" or "No." Empty space was provided for them to write the reasons for their answers, if they thought it was necessary. The students' answers to the four questions are shown in Table 3.

TABLE III

\begin{tabular}{|c|c|c|c|c|c|}
\hline \multirow{3}{*}{ NNo } & \multirow{3}{*}{ Questions } & \multirow{2}{*}{\multicolumn{2}{|c|}{ "Yes" }} & \multirow{2}{*}{\multicolumn{2}{|c|}{ "No" }} \\
\hline & & & & & \\
\hline & & $\mathrm{N}$ & $\%$ & $\mathrm{~N}$ & $\%$ \\
\hline 1 & $\begin{array}{l}\text { Did the process in the video-making project help you in } \\
\text { determining the topic for your essay? }\end{array}$ & 22 & 88 & 3 & 12 \\
\hline 2 & $\begin{array}{l}\text { Did the process in the video-making project help you in } \\
\text { developing your topic into the thesis statement of your essay }\end{array}$ & 23 & 92 & 2 & 8 \\
\hline 3 & $\begin{array}{l}\text { Did the process in the video-making project help you in } \\
\text { expanding your thesis statement into the development } \\
\text { paragraphs of your essay? }\end{array}$ & 24 & 96 & 1 & 4 \\
\hline 4 & $\begin{array}{l}\text { Did the process in the video-making project help you in } \\
\text { writing the concluding paragraph of your essay? }\end{array}$ & 17 & 68 & 8 & 32 \\
\hline
\end{tabular}

Table 3 shows that the majority of the students perceived the video-making project helped them in developing ideas for their essays with the exception of the concluding paragraph. This means that the video-making project help them in determining the topic for their essay (Question \#1), in developing their topic into the thesis statement of their essay (Question \#2), in expanding their thesis statement into the development paragraphs of their essay (Question \#3), with the total number of $22(88 \%), 23(92 \%)$, and $24(96 \%)$ of the students, respectively.

However, with regard to the question on whether or not the video-making project helped them in writing the concluding paragraph of their essay (Question \#4), about one-third of the students (32\%) thought that they were not helped by the video-making project. The examination of the students' reasons for their perception revealed that these students have been helped by their thesis statement (Student 6) or the developmental paragraphs (Students $8,10,11 \&$ 15). For example, Student 6 stated, "No, because I conclude my paragraph ... from the thesis statement and topic I already talk in the previous paragraph," meanwhile Student 8 stated, "No, because basically the conclusion is taken by concluding developmental paragraphs and giving/adding my opinion." In addition, beyond the two reasons, one student (Student 20) found difficulty in writing the concluding paragraph regardless of the video-making project. This student stated, "No, because when I did my concluding paragraph I still find it hard."

The second research question deals with how the students perceived the meaningfulness of the essay writing project. There were five questionnaire items in this part. Responses to the options were given values from 5 ("strongly agree") to 1 (strongly disagree). However, for Questionnaire Item \#2 the reverse value was given due to the opposite nature of the item. This item stated that "The work I do in essay writing class is a waste of time" which expected the students' disagreement. The average score of the students' responses for each questionnaire item is shown in Table 4.

TABLE IV

EFL STUDENTS’ PERCEPTIONS ON THE MEANINGFULNESS OF ESSAY WRITING PROJECT

\begin{tabular}{|c|c|c|c|c|}
\hline No & Questionnaire Items & $\begin{array}{l}\text { Total } \\
\text { value }\end{array}$ & $\mathrm{N}$ & Average \\
\hline 1 & The work I do for Essay writing class is valuable to me. & 113 & 25 & 4.52 \\
\hline 2 & The work I do in Essay writing class is a waste of time. & 110 & 25 & 4.40 \\
\hline 3 & $\begin{array}{l}\text { The activities during the writing class improve my understanding } \\
\text { of the exemplification essay. }\end{array}$ & 105 & 25 & 4.20 \\
\hline 4 & Making video project prepared me for the essay writing activity. & 103 & 25 & 4.12 \\
\hline 5 & $\begin{array}{l}\text { Watching the video that has been made is helpful for the essay } \\
\text { writing process. }\end{array}$ & 107 & 25 & 4.28 \\
\hline
\end{tabular}

Table 4 shows that all of the students' responses to the questions are favourable as all of the scores are above 4 value. Regarding Questionnaire Item \#1, the students perceived that they were in between agreed and strongly agreed, meaning that the work they did for essay writing class was valuable for them. For Questionnaire Item \#2, due to the opposite nature of the question, the students' average score indicated that they disagreed with the statement that the work they did in essay writing class is a waste of time. Pertaining to Questionnaire Item \#3, it was found out that the students agreed that the activities during the writing class improved their understanding of the exemplification essay. 
Furthermore, students' responses to Questionnaire Items \#4 and \#5 indicated they agreed that making video project prepared them for the essay writing activity and watching the video that they made was helpful for the essay writing process. Thus, the analysis of the students' responses suggested that they have positive perceptions toward the meaningfulness of the implementation of the essay writing project.

The third research question pertains to the students' perception on their competence after working on the essay writing project. The responses of the students to the five questions asking their perceptions of their competence are shown Table 5.

TABLE V

EFL STUDENTS’ PERCEPTIONS ON THEIR COMPETENCE IN ESSAY WRITING

\begin{tabular}{|c|c|c|c|c|}
\hline No & Questionnaire Items & Total value & $\mathrm{N}$ & Average \\
\hline 6 & I can do well in my essay writing class. & 94 & 25 & 3.76 \\
\hline 7 & I am confident about my ability to write an exemplification essay. & 94 & 25 & 3.76 \\
\hline 8 & Collaborative work in video-making helps me to improve my writing. & 91 & 25 & 3.64 \\
\hline 9 & $\begin{array}{l}\text { Because of the project, I can easily understand how to write an } \\
\text { exemplification essay. }\end{array}$ & 103 & 25 & 4.12 \\
\hline 10 & I have what it takes to do well in essay writing class. & 99 & 25 & 3.96 \\
\hline
\end{tabular}

Table 5 depicts that all of the students' average score for the five questions are close to 4 value, meaning that they all have positive perceptions about their competence related to the Essay Writing. More specifically, the table showed that the students agreed that they could do well in their essay writing class (Questionnaire Item \#6) and they also agreed that they were confident about their ability to write an exemplification essay (Questionnaire Item \#7). Moreover, they thought that collaborative work in video-making helped them to improve their writing (Questionnaire Item \#8). They also perceived that the project in essay writing enabled them to understand how to write an exemplification easily (Questionnaire Item \#9). Finally, the table shows that the students agreed that they had what it takes to do well in the essay writing class (Questionnaire Item \#10). All in all, the students believed that they achieved good competence dealing with their ability in essay writing and one of the reasons for this was their participation in the essay writing project.

\section{DisCUSSION}

This study has been situated in the context of integrating culture and innovation in ELT, more particularly in the teaching of exemplification essay writing. The culture element was reflected in the topics of the students' essays, while the innovation was apparent from the use of technology in the form of student-made videos. The results of the analysis are highlighted in reference to the three research questions.

The first research question deals with how the students perceived the video-making project as a means of developing ideas for their essays. An essay is a composition containing three parts: the introduction which contains the thesis statement, the body of the essay or the developmental paragraphs, and the conclusion (Smalley et al., 2001; Oshima \& Hogue, 2007). The results of the study shows that students perceived that the process they undertook in video-making guided them in determining the topics of their essays, developing the topic into thesis statement, developing thesis statement into developmental paragraphs, and concluding the essays. The video-making process was beneficial in helping the students to write in a foreign language, a skill which is considered to be very complex (Richards \& Renandya, 2002). Thus, the difficulty in developing ideas in writing which is usually encountered by EFL learners can be overcome through the implementation of the essay writing project, with an element of video-making. The use of the video in ELT in this study is in line with the strategies in using videos suggested by Nurcahyasari (2015), while the inclusion of student-made videos in writing exemplification essays support a study conducted by Cahyono and Rahayu (2015) which shows that video-based tasks enabled the students to write process-analysis essays better.

Pertaining to the second research question, the result of the present study indicated that the students thought that the essay writing project was meaningful for them. The essaywriting project was assigned to the students through a series of stages: Discussing about a topic in groups (planning), writing a thesis statement leading to paragraph development by using examples (drafting), documenting the settings for the topic through video-making, and writing (revising) the essay individually. This means that the stages which reflect process writing were meaningful for the students. Moreover, the inclusion of the local cultures as the topic helped them in the process of writing. In fact, all of the groups of students working on the project decided to choose topics within the types of cultural contents proposed by Cortazzi and Jin (1999), namely "social and political institutions" (i.e., Famous Universities, Facilities at ESAC, UM, and Canteens), "stereotypes and national identity" (i.e., Iconic Parks \& Foods), and "belief and behavior," (Car Free Day), with which the students were familiar. This study is in line with the result of the study conducted by (Cahyono, Amelia, \& Mutiaraningrum, 2016) which shows that students found out easier to write about general and personal topics compared to writing academic topics.

In addition to the students' perception on the meaningfulness of the essay writing project, they students were also asked about their perception on their competence following the implementation of the writing project. In general, as the students perceived, their competence in writing exemplification essays were above the average. This happened in various aspects of essay writing, such as in taking part in the essay writing activities, in working collaboratively with 
classmates, and in doing their best at the course. In reference to Hinkel's (1999) and Wehmeier's (2005, p. 373) concepts of cultures, the students have created their own culture in attending Essay Writing course as they thought that what they have conducted in the course encouraged them to think, feel and do "what it takes to do well" in the course. This is also evident from the innovative process in writing exemplification essays and the presentation of the essays which were viewed positively by the students.

\section{CONCLUSION}

This study has integrated culture and innovation in essay writing course by focusing on cultural contents (i.e., topics of the essays) and the way to present the cultural contents (technologically oriented process in making videos related to the topics and the presentation of the essays). The culture and innovation elements were integrated in the project in writing exemplification essays. More importantly, it has examined the perceptions on the video-making project as a means of developing ideas for their essays, the meaningfulness of the essay writing project, and their competence after working on the essay writing project. Overall, the results of the study indicated the positive perceptions of the students. This means that the students were helped in some ways in the development of the essays by the process of video making. They also thought that the essay writing project was meaningful and they were confident about their competence in writing after following the essay writing project. A lesson learned from the implementation of this study is that topics related to culture contents (things which are usually seen as old-fashion) could be successfully integrated with technologically oriented process (things which are considered innovative). This implies that English language teachers should consider applying the two seemingly contradictory elements in English classrooms.

\section{APPENDiX A. A SAMPLE ESSAY}

\section{The Most Famous Universities in Malang, Indonesia}

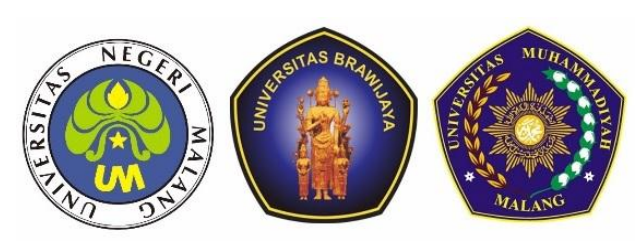

As "The City of Students," Malang has many universities. Among those universities, there are some which have been known as the most famous ones. Universitas Negeri Malang, University of Brawijaya, and University of Muhammadiyah Malang become the most famous universities in Malang due to their well-facilitated campuses.

With its motto, The Learning University, Universitas Negeri Malang or UM has been known as a campus that put the learning systems and activities in the top place. To support the students' learning, UM provides good facilities for them. There is a huge hall named Graha Cakrawala. It is not only used for graduation ceremony, but also used for students' activities and events such as competetions, conferences, and musical concerts. There are also courts for students to do some sports like basketball, futsal, tennis, and also volleyball. Even UM has a clean swimming pool and a football stadium. Students can improve their ability in sports using those facilities. For moslem students, UM provides a mosque named Al-Hikmah. Moslems can pray and follow the Islamic seminars here. UM also has a huge library with thousands of books inside. Students can look for information about their subjects in the library. Those facilities make UM famous and make students want to study there.

University of Brawijaya or UB is well-known as one of the best universities in Indonesia. With that predicate, UB tries to provide its students with the best facilitates. UB has a hall named Samantha Krida which is usually used for the graduation ceremony. It is also used for certain events, like competitions and conferences. UB also has a handsome rectorate building for administrational businesses. Students come to rectorate building when they need some problems with lectures schedules, the fees, and so on. However, UB also thinks about their moslem students. They provide a great mosque named Raden Patah. It has Javanese architecture, like most of the UB buildings. Raden Patah mosque is a clean and comfortable mosque where the moslems can pray. Nevertheless, UB has a very great library with thousands books as collections. With all of the facilities, UB becomes the favorite destination for the students to study at.

University of Muhammadiyah Malang or UMM is a famous private university in Malang. Being a private university does not make UMM be careless about their students' learning activities. On the other hand, UMM provides the students' learning with many good facilities. There is UMM Dome, a huge building with many functions. It can be used either for academic events like conferences or non academic events like musical concerts. UMM also supports their students in sports by providing sport facilities such as basketball court, futsal court and so on. There is also a big mosque named A.R Fachruddin for moslem students. Besides, UMM does not forget the students' activities in organizations. UMM has a Student Center, a comfortable building which provides a room for each organization. So the students do not need to seek for places when they want to gather with the members in an organization. Moreover, UMM has a big library which can support the students' learning with sources from thousand of books. With all of the facilities, UMM becomes famous and attracts many students to study there. 
UM, UB, and UMM become famous because they have good facilities to support their students' learning. You should be proud if you are studying at one of these universities (By Salsabila Ramadhani Imanda).

\section{APPENDIX B. THE QUESTIONNAIRE}

Instruction: In this Essay Writing course, you were required to write an exemplification essay based on Culturally and Technologically Oriented Essay Writing Project. This questionnaire aims to know how you see the process in developing ideas into an essay. Please give your responses to the following questionnaire items.

PART 1: Developing Ideas into Essay

1. Did the process in the video-making project help you in determining the topic for your essay?

$\begin{array}{ll}\text { a. Yes } & \text { b. No }\end{array}$

Why (why not)?

2. Did the process in the video-making project help you in developing your topic into the thesis statement of your essay?
a. Yes
b. No

Why (why not)?

3. Did the process in the video-making project help you in expanding your thesis statement into the development paragraphs of your essay?
a. Yes
b. No

Why (why not)?

4. Did the process in the video-making project help you in writing the concluding paragraph of your essay?
a. Yes
b. No

Why (why not)?

Give your response by crossing the appropriate letter of the options.

PART 2: Meaningfulness

1. The work I do for Essay writing class is valuable to me.

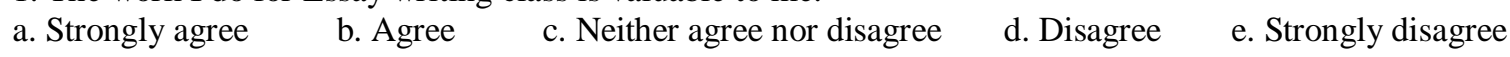

2. The work I do in Essay writing class is a waste of time.

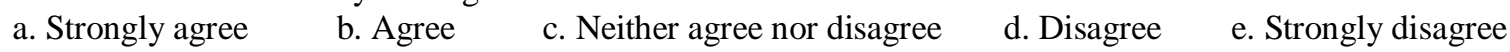

3. The activities during the writing class improve my understanding of the exemplification essay/.

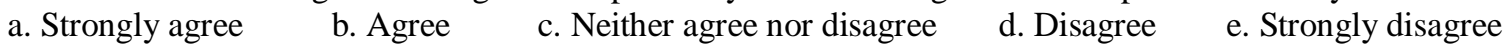

4. Making video project prepared me for the essay writing activity.
a. Strongly agree
b. Agree
c. Neither agree nor disagree
d. Disagree e. Strongly disagree

5. Watching the video that has been made is helpful for the essay writing process.
a. Strongly agree
b. Agree
c. Neither agree nor disagree
d. Disagree
e. Strongly disagree

PART 3: Competence

6. I can do well in my essay writing class.
a. Strongly agree
b. Agree
c. Neither agree nor disagree

7. I am confident about my ability to write an exemplification essay.

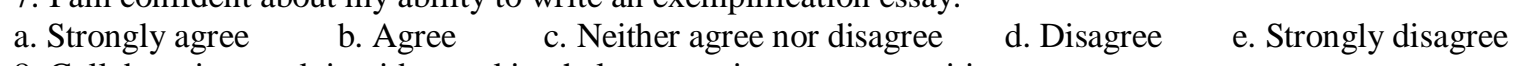

8. Collaborative work in video-making helps me to improve my writing.
a. Strongly agree
b. Agree c. Neither agree nor disagree
d. Disagree
e. Strongly disagree

9. Because of the project, I can easily understand how to write an exemplification essay.
a. Strongly agree
b. Agree
c. Neither agree nor disagree
d. Disagree
e. Strongly disagree
10. I have what it takes to do well in essay writing class.
a. Strongly agree
b. Agree
c. Neither agree nor disagree
d. Disagree
e. Strongly disagree

\section{REFERENCES}

[1] Asmiyah, S. (2009). Are there advantages in using topics about Islam to develop the English writing skills of Indonesian students in Islamic colleges? Unpublished Masters Thesis. Melbourne, VIC: Victoria University.

[2] Cahyono, B. Y., \& Rahayu, T. (2015). Using video-based tasks for teaching writing process analysis essay. In B. Y. Cahyono (Ed.), Inspirations and innovations for English classroom (pp. 345-362). Malang: State University of Malang Press.

[3] Cahyono, B. Y., Amelia, R., \& Mutiaraningrum, I. (2016). Apprehension, topic variety, and proficiency in writing of Indonesian EFL students. Studies in English Language Teaching, 4(3), 314-329.

[4] Cortazzi, M., \& Jin, L. (1999). Cultural mirrors: Materials and methods in the EFL classroom. In E. Hinkel (Ed.), Culture in second language teaching and learning (pp. 196-219). Cambridge: Cambridge University Press.

[5] Hinkel, E. (1999). Introduction: Culture in research and second language pedagogy. In E. Hinkel (Ed.), Culture in second language teaching and learning (pp. 1-7). Cambridge: Cambridge University Press.

[6] Imran, N. (2006, December). The interplay of culture, individual differences and adult EFL reading performance: From teacher-dependence to the development of autonomous readers. Paper presented in the 54th TEFLIN International Conference held in Salatiga, Indonesia.

[7] Kramsch, C. (1998). Language and culture. Oxford: Oxford University Press. 
[8] Luciana. (2005). Whose culture: Your culture? My culture? A case of English language learning in Indonesia. In S. A. Bruce \& A. Suratno (Eds.), Representation of cultural values in language and literature: Proceeding of conference on culture, English language teaching and literature (pp. 71-80). Semarang: Soegijapranata Catholic University.

[9] Murniati, C. T. (2005). Cross-cultural barriers: Exploring conflicting expectations btween native speaking teachers and Indonesian learners of English. In S. A. Bruce \& A. Suratno (Eds.), Representation of cultural values in language and literature: Proceeding of conference on culture, English language teaching and literature (pp. 93-100). Semarang: Soegijapranata Catholic University.

[10] Nurcahyasari, F. (2015). Utilizing video in ESL/EFL classroom: Proposition of an alternative strategy. In B. Y. Cahyono (Ed.), Inspirations and innovations for English classroom (pp. 363-378). Malang: State University of Malang Press.

[11] Oshima, A., \& Hogue, A. (2007). Introduction to academic writing. New York: Pearson Education.

[12] Richards, J. C., \& Renandya, W. A. (2002). Methodology in language teaching: An anthology of current practice. Cambridge: Cambridge University Press.

[13] Rokhyati, U. (2005). Integrating culture in the teaching of English through the use of authentic texts. In S. A. Bruce \& A Suratno (Eds.), Representation of cultural values in language and literature: Proceeding of conference on culture, English language teaching and literature (pp. 47-56). Semarang: Soegijapranata Catholic University.

[14] Smalley, R. L., Ruetten, M. K., \& Kozyrev, J. R. (2001). Refining composition skills. Rhetoric and grammar. Boston, MA: Heinle \& Heinle.

[15] Wehmeier, S. (Ed.). (2005). Oxford anvanced learner's dictionary. Oxford: Oxford University Press

[16] Yujing, N. (2015). Influence of flipped classroom on learner's empowerment-a study based on English writing courses in China. Journal of Literature, Languages and Linguistics, 12, 1-7.

[17] Zu, L., \& Kong, Z. (2009). A study on the approaches to culture introduction in English textbooks. English Language Teaching, 2(1), 112-118.

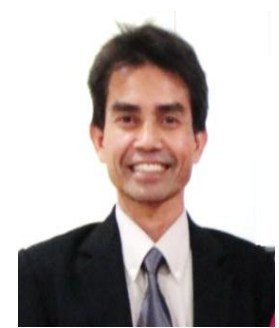

Bambang Yudi Cahyono is a Professor in Applied Linguistics at Universitas Negeri Malang, East Java, Indonesia. He earned his M.A. degree from Concordia University, Montreal, Canada, and Ph.D. from the University of Melbourne, Australia. His research interest includes the Teaching of EFL writing, English teacher professional development, and ICT in ELT. E-mail: yudic2000@yahoo.com; bambang.yudi.fs@um.ac.id 